\title{
"Police Free Gay Slaves": Consent, Sexuality, and the Law
}

\section{Bernardo Alexander Attias}

On 11 January 1995, the European Court of Human Rights in Strasbourg agreed to hear a complaint against Great Britain by three gay men imprisoned for sado-masochistic sexual practices in the infamous "Operation Spanner" case. ${ }^{1}$ This international hearing addressed the vital question, "If a man wants his scrotum sandpapered in the privacy of his own home, is it anybody else's business?"2 The complaint to the Court arose after the United Kingdom had sentenced sixteen men to prison for engaging in consensual sado-masochistic sexual activities; specifically, among other things, "nailing each other's willies to the skirting board." 3 The men were convicted on assault charges; the case was unusual in that the evidence against them was a set of videotapes of the activity rather than the testimony of any victim. Since the activity itself was entirely consensual, there was no complaining witness in any of the cases. ${ }^{4}$

The Commission eventually rejected the men's complaint, ruling that the state has the right to interfere in the private lives of its citizens "to protect public health and morals."5 One commentator called the day of the Commission's decision "a black day for human rights in Europe," arguing that the Commission's Judge Pettiti “displays a contempt for individual freedom unrivalled even by the Thought Police in Orwell's 1984."' Underlying such condemnations of the Commission's judgment is an insistence that the government stay out of the affairs of consenting adults. It is presumed by critics that the state should not interfere with the consensual sexual activities of individuals, no matter how bizarre such activities might seem to others. ${ }^{7}$ Because the men involved consented to the activities they engaged in, it is argued, any physical harm sustained by the participants should be deemed no more injurious to "public health and morals" than similar injuries that might occur during a particularly vigorous boxing match or a mountain climb.

This essay is an attempt to understand the discursive apparatus surrounding sexual consent in the broader context of the history of the Anglo-American juridico-legal repression of sexuality. The goal of this essay is to make a few observations about the production of erotic subjectivities through juridico-legal discursive machinery. ${ }^{8}$ I have chosen a rather circuitous route to this goal. Rather than approaching the problem systematically in order to arrive at final conclusions, I have chosen to analyze a cluster of events in Anglo-American juridico-legal history in order to tease out some of the implications of the way in which certain assumptions about "consent" circumscribe erotic identities.

55

(C) Left History

10.1 (Fall/Winter 2004) 
Underlying this methodology is an understanding of the role of historical scholarship as not just an interested recording and re-telling of events but also as a performative act in its own right. My choice of case studies is by no means canonical and may even seem haphazard. I have chosen these cases thematically rather than systematically. The project of laying out an exhaustive history of the discursive apparatus at work here is beyond the scope of this essay. My goal instead is to get at certain themes in the treatment of "consent" with an eye toward the role of the legal system in producing erotic subjectivities. While I am in part attempting to bring to light a hidden history of the relationship between sexuality and the law, my main purpose is not to provide an exhaustive or even authoritative version of this history, but rather to choose historical incidents in which the questions of consent that I am trying to understand are evoked most explicitly. ${ }^{9}$

In looking at the framing of consent in various cases, including those where sadomasochistic sexual practices are at issue, one finds seemingly paradoxical inconsistencies. It is my contention that such inconsistencies are actually different facets of a coherent discursive formation; that is, products of an underlying power dynamic that produces subjects as erotic identities.

\section{Rethinking Consent and Assault: The S/M Cases}

On 10 April 1976, 107 members of the Los Angeles Police Department swarmed over a Hollywood bathhouse to arrest 40 men (after detaining 80 ) for violating an 1899 California law against slavery. ${ }^{10}$ The men arrested were participating in a mock slave auction as a fund-raising benefit for gay organizations. LAPD officials had been preparing the raid for several months beforehand, and when the raid went down, they brought the media with them. Between 5:20 AM and 5:40 AM the morning after the raid, "Capt. Wilson, the field commander for the operation, had given interviews to 3 radio stations and one print journalist."11 Val Martin, the "slave auctioneer" at the benefit, recalls:

a very groovy guy comes to me with a leather jacket and a leather cap, torn jeans, very good looking. And he comes to me and asks what is the price of these slaves, so I told him. ... He asked me if he (the slave) was a good cocksucker; I said 'sure' and he said, "Well, I have a big dick, do you think that he can suck my big dick?" So I said, "Sure, as a matter of fact they call him 'Jaws."' I was just kidding around.... as soon as I said "sold" and received the money from him, the whole thing comes down. He gives a signal to the rest of the police and a couple of helicopters, three or four TV cam- 
eras, and 120 policemen surrounded the premises, even on top of it. ${ }^{12}$

The entire cost to the City of Los Angeles of the raid was conservatively estimated at $\$ 150,000$. The day after the raid, the Orange County Register's frontpage headline screamed, "Police Free Gay Slaves." The paradoxical impropriety of this sentence, its irony seemingly lost on the paper's editors, was characteristic of the LAPD's and the prosecutor's version of the events of the raid; the Pasadena Star News, for example, quoted one police officer as saying, "we went in and liberated them." 13 Of course, this "liberation" involved handcuffing the defendants, forcing them to kneel or lie face down, then carting them in a crowded bus to jail for processing, denying them the opportunity to use the toilet, and taunting and photographing them at the police station. ${ }^{14}$

The headline that the editors of the Register constructed to describe the raid is not only ironic; it also falls into the category of catachresis: an abuse of language. Gayatri Spivak has noted that such abuses can be intellectually productive. ${ }^{15}$ In her essay "Can the Subaltern Speak?" Spivak looked briefly at the sentence that Freud constructed from his female patients' accounts of masochistic sexual fantasies: "A child is being beaten."16 Freud's sentence is catachrestic in that the isomorphic analogy suggested between subject-formation and collective behavior is overly simplistic, but it is productive in that it allows her to highlight the fact that the sentence predicates a history of repression with a doubled origin. I think the obviously catachrestic sentence "police free gay slaves" allows for a similarly productive reading. In the case of Freud's sentence, the doubled origin of repression is both in the amnesia of the infant and in the archaic past (assuming the useful fiction of a moment in human history prior to and outside of the history of sexuality). The sentence assembled by the editors of the Orange County Register predicates a history of repression with two origins as well: one in the specific circumstances surrounding the Mark IV Raid and the other in the history of the relationship between the law, consent, and "sexual perversion". 17

Michel Foucault has shown how varieties of the "sexual pervert" were constructed in medical and juridical discourse during the Victorian era. For Foucault, the "perverse" sexualities that were recorded and categorized during the Victorian era were not ahistorical personality traits that existed prior to their recording. Rather, they were produced and consolidated as such through this discursive process. This is not to say that the discourse of power "created" perversion but rather that it made certain that each perversion had a name, a trajectory, a personality, and a detailed account of itself. ${ }^{18} \mathrm{He}$ focuses on certain themes in the discourse of power and pleasure in order to get at some of the implications of what he calls the "perverse implantation". "Modern society is perverse," he writes, "not in spite of its puritanism or as if from a backlash provoked by its hypocrisy; it is in actual fact, and directly, perverse." 19 
According to Foucault, power functions not by repression primarily, but rather by the discursive production of sexual identities. This does not, of course, mean that sexuality is not repressed in Western cultures. As Gayle Rubin argues in "Thinking Sex," Foucault's analysis of the repression hypothesis in volume one of the History of Sexuality does not deny the existence of political repression of sexuality in Western societies. ${ }^{20}$ In fact, Western history is rife with instances of sexual repression induced by moral panic. What Foucault does is point out that repression is not the only or even the primary function of power. The exercise of power as repression takes place in service to power's primary function, which is productive. Power produces sexual identities in a positive, rather than exclusively negative, manner.

We see this argument about the nature and function of power at work in Foucault's analysis of sexuality, as well as in his histories of madness, disease, and the prison system. In lectures at the College de France in 1975 which laid some of the groundwork for History of Sexuality, he illustrated this concept in relation to the history of disease, specifically in the transition he notices from the model of leprosy to the model of the plague, calling it "the invention of positive technologies of power":

The reaction to leprosy is a negative reaction; it is a reaction of rejection, exclusion, and so on. The reaction to plagues is a positive reaction; it is a reaction of inclusion, observation, the formation of knowledge, the multiplication of effects of power on the basis of the accumulation of observations and knowledge. We pass from a technology of power that drives out, excludes, banishes, marginalizes, and represses, to a fundamentally positive power that fashions, observes, knows, and multiplies itself on the basis of its own effects. ${ }^{21}$

This dynamic is precisely what is at work in the history of sexual perversion: we have moved from the exercise of power as repression, exclusion, banishment, to the exercise of power as production through the refinement of a disciplinary discourse. Foucault argues in History of Sexuality that when it comes to the relation of power to sexuality, what is at work is not so much "a negative mechanism of exclusion" but rather "the operation of a subtle network of discourses, special knowledges, pleasures, and powers." He continues:

At issue is not a movement to push rude sex back into some obscure and inaccessible region, but on the contrary, a process that spreads it over the surface of things and bodies, arouses it, draws it out and bids it speak, implants it in reality and enjoins it to tell the truth: an entire glittering sexual array, reflected in a myriad of discourses, the obstination of powers, and the interplay of knowledge and pleasure. ${ }^{22}$ 
The sexual pervert in the Victorian era is not "repressed" in the sense of being banished or rendered invisible; rather, $\mathrm{s} /$ he is rendered visible by a discourse that makes that visibility a locus of control.

It is clear that the Mark IV Raid, like the Spanner case in England, represents a significant historical moment in the more recent history of the perverse implantation. The figure of the "gay slave" mobilized in the discourse surrounding these events has historical significance as a conduit of power and resistance in specific historical circumstances, rather than simply as a manifestation of the sadomasochist studied by Krafft-Ebing or Reik.

It is well known that throughout the 1990 s, conservatives in the United States went to great extremes to demonize the movement for anti-discrimination laws for lesbians, gays, and bisexuals by associating the "gay agenda" with the abuse of children and with disease and moral decay. ${ }^{23}$ This moral panic $^{24}$ included nationwide attempts to repeal or declare illegal any mention of sexuality in anti-discrimination statutes and perhaps revealed itself at its most ludicrous in the resignation of Surgeon General Jocelyn Elders over (among other things) a comment about masturbation. ${ }^{25}$

In particular, fundamentalist pundits appropriated exaggerated representations of sadomasochism and the leather communities from gay pride parades and used these images to vilify gay men, lesbian, and bisexuals as "perverts" and "freaks." The film The Gay Agenda, for example, which was mass-produced for popular audiences and hand-delivered to political representatives, extensively used images from the leather community as a rhetorical tool to demonize the gay community as perverse and unworthy of civil rights. ${ }^{26}$ Antigay activists chose the most exaggerated images of S/M sex they could find in order to demonize the entire gay community (and, by extension, anyone who would advocate an understanding of homosexual behavior as socially acceptable).

What is striking about this appropriation is not that it has been successful in its aim of synecdochically demonizing the gay community at large. In fact, it backfired dramatically from that perspective, as evidenced by the increasing cultural and social presence of positive images of the gay community coupled with a decreased tolerance for open attacks on gays in the form of violence or police harassment. ${ }^{27}$ And the iconography of this sort of "perversity" - whips, collars, cuffs, leather clothing, etc. - has become a distinct facet of mainstream popular culture.

Rubin argues that moral panics of this type should be read as the " political moment' of sex, in which diffuse attitudes are channeled into political action and from there into social change." She continues:

Because sexuality in Western societies is so mystified, the wars over it are often fought at oblique angles, aimed at phony targets, conducted with misplaced passions, and are 
highly, intensely symbolic. Sexual activities often function as signifiers for personal and social apprehensions to which they have no intrinsic connection. During a moral panic, such fears attach to some unfortunate sexual activity or population. The media become ablaze with indignation, the public behaves like a rabid mob, the police are activated, and the state enacts new laws and regulations. When the furor has passed, some innocent erotic group has been decimated, and the state has extended its power into new areas of erotic behavior. ${ }^{28}$

In the Mark IV case, what was on trial was not the violation of the laws against slavery or pandering (which the Mark IV prosecution had reduced the charges to after the District Attorney refused to degrade his office further by continuing to prosecute absurd charges of "slavery"), but rather the sexuality of the accused. ${ }^{29}$ As defense attorney Thomas Hunter Russell argued in the Mark IV trial, "what is really on trial here is the sexual orientation of the defendants, and not their specific behavior with regard to a particular section of the Penal Code. $" 30$

Interestingly, while the Mark IV case was prosecuted as a pandering case, charges of assault were never brought against the defendants for any sadomasochistic acts that may have taken place at the auction. The question of consent was raised only indirectly through the symbol of the "gay slave" awaiting "liberation" by police. The prosecution in the Spanner case, however, focused primarily on such charges, regardless of Lord Mustill's protest that the case should be about "private sexual relations". It is worth briefly examining the discussion of this case in the House of Lords because the arguments surrounding the issue of consent are made explicitly.

For Lord Templeman, who found with the 3-2 majority in Regina $v$. Brown, there is no question of raising a "consent" defense to the assault charges. The sadomasochistic activities participated in by the defendants are part of a "cult of violence" that society is both "entitled and bound to protect itself against." He continues, "Pleasure derived from the infliction of pain is an evil thing. Cruelty is uncivilised." 31 Lord Templeman is careful to argue that sadomasochistic sexual practices injure society as well as the specific "victim"; thus, the consent of the victim does not legalize conduct that would otherwise be regarded as assault.

Lord Jauncy went even further, arguing that society must be protected not only from a general "cult of violence" but from the more specific social danger of sadomasochistic recruiting. While the defendants were never charged with crimes specifically for videotaping their activities, Lord Jauncy argues that such taping was in no way innocent: 
Furthermore, the possibility of proselytisation and corruption of young men is a real danger even in the case of these appellants and the taking of video recordings of such activities suggests that secrecy may not be as strict as the appellants claimed to your Lordships. If the only purpose of the activity is the sexual gratification of one or both of the participants what then is the need of a video recording? ${ }^{32}$

The majority in Regina v. Brown dealt with the issue of consent by emphasizing the immoral purpose at work in sadomasochistic activities. If someone is injured during a game of rugby, his or her consent would invalidate any assault charges that might arise from the injuries. The difference between this hypothetical example and the behavior at issue in Brown is the difference "between violence which is incidental and violence which is inflicted for the indulgence of cruelty." In organized sports, Lord Templeman continued, the "danger to life and limb is merely incidental to the main purpose of the activity." 33

In an article in the Texas Journal of Woman and the Law, Monica Pa criticizes the judgment in Brown, arguing that the Lords' decision legalizes discrimination specifically against homosexual S/M sexual practices. While Lord Templeman declared himself unprepared "to invent a defence of consent for sado-masochistic encounters which breed and glorify cruelty," Pa points out that what the court actually did instead was invent a new crime. The 1861 law (Offenses Against the Persons Act) that was used to convict the defendants "clearly intended to penalize conduct of a quite different nature," as Lord Mustill put it in his dissenting opinion. For $\mathrm{Pa}$, the decision is a manifestation of the Lords' homophobia. "All three Lords in the majority," she points out, "recognized the comfort they received from knowing that one of the younger participants, K., 'has now settled into a normal heterosexual relationship'."34 And a later case, Regina v. Wilson, in which the court held that a wife's consent to having her husband's initials branded on her buttocks was a legitimate defense against an assault charge, suggests that, as Sangeetha ChandraShekeran points out, "despite the conception of S/M sex as violence, acts involving similar 'violence' within an authorized heterosexual relationship are not subject to the same level of public interference." 35

Although the cases are very different, at stake in both the Mark IV and the Spanner cases is a moral rejection of the sexuality of the defendants. Pa underlines this point with reference to the "unusually severe" sentences imposed by courts in such cases. In Brown the defendants received sentences of up to four and a half years. The Mark IV defendants were threatened with five-to-ten year sentences, which were eventually plea-bargained to much shorter terms. Other cases have seen more serious sentences, in many cases far exceeding the typical sentences given for nonconsensual rape or assault. ${ }^{36}$ In such cases it 


\section{$62 \quad$ Attias}

becomes clear that the defendants' sexuality, and not just specific illegal activities, is what is on trial.

\section{Rethinking Consensual Sodomy: Lawrence v. Texas}

In order to better understand the role played by consent in the Anglo-American legal imaginary, it is worth briefly looking at the treatment of consensual homosexual sodomy that is not related to $\mathrm{S} / \mathrm{M}$ activities. Once illegal in many US states, homosexual activity has been given the stamp of approval of the highest court in the land. The court's 2003 decision in Lawrence v. Texas overturned its infamous 1986 decision upholding the constitutionality of state sodomy laws. ${ }^{37}$ The decision has been hailed as a constitutional victory by gay rights activists and civil libertarians alike. Bruce Steele characterized the decision in The Advocate as a victory for sexual liberation: "The historic magnitude of the US Supreme Court's Lawrence v. Texas decision, invalidating all remaining US sodomy laws, is equal to that of the Stonewall uprising. It will resonate for decades." ${ }^{38}$ The decision was equally passionately vilified by its critics. In a vitriolic dissent, Justice Scalia called the decision "a product of a law-profession culture that has largely signed on to the so-called homosexual agenda." 39 Scalia predicted a "massive disruption of the current social order" in a classic instance of the "slippery slope" argument: grant constitutional protection to sodomy, he warned, and you must be prepared to grant such protection to everything from gay marriage to bestiality. ${ }^{40}$ Scalia noted:

State laws against bigamy, same-sex marriage, adult incest, prostitution, masturbation, adultery, fornication, bestiality, and obscenity are likewise sustainable only in light of Bowers' validation of laws based on moral choices. Every single one of these laws is called into question by today's decision.... ${ }^{41}$

Of course, the slippery slope metaphor is a relatively obvious logical fallacy, not the least because of the arbitrariness of any decision regarding where the slope begins to slip. ${ }^{42}$ But it is worth focusing momentarily on Scalia's rationale, which turns on the question of moral choice, and ultimately, an individual's right to engage in consensual sexual activity. Scalia's feeling is that the core significance of Bowers is the "validation of laws based on moral choices." At issue, from Scalia's perspective, is a state's right to make its own choices regarding individual morality. Of course, from the perspective of the court's majority, it is the question of the individual's right to make his or her own choices regarding individual morality that is at stake. ${ }^{43}$ Justice Kennedy spelled this out clearly in his majority opinion, emphasizing the important role of consent in distinguishing between behavior that would be protected by the Constitution and behavior that would not: 
The present case does not involve minors. It does not involve persons who might be injured or coerced or who are situated in relationships where consent might not easily be refused.... The case does involve two adults who, with full and mutual consent from each other, engaged in sexual practices common to a homosexual lifestyle. ${ }^{44}$

The obstacle that prevents us from sliding down the slippery slope, for Kennedy, is consent; constitutional protection is not expected to be extended to behavior that is nonconsensual. For Kennedy, homosexual activity deserves constitutional protection because it involves private behavior by consenting individuals. Of course, many supporters of sodomy statutes reject this argument quite explicitly, and state that individual consensual private behavior is not protected by the Constitution.

Scalia, however, seems to carefully avoid making such rejection explicit in his dissent. He rarely mentions the word and never addresses the consent issue directly, and he only mentions "privacy" twice. He insists, like Justice White did in Bowers v. Hardwick, on narrowing the constitutional issue at stake to the question of whether there is a "fundamental right" to engage in homosexual sodomy. Justice Thomas, in his brief rejoinder to Scalia, is at least more forthright in his rejection of the notion that there is a constitutional right to privacy at all..$^{45}$

The difference between Kennedy and Scalia over the question of consent highlights the problem in the Anglo-American legal tradition that the present study attempts to understand. While it is clear that Kennedy's opinion holds that consent of the individuals involved makes the liberty to engage in conduct a constitutionally protected liberty, it is not clear whether Kennedy would be willing to extend that logic to the kind of behavior at issue in such cases as Regina v. Brown. In societies which are clearly liberalizing their views towards consensual sexual activity, what precisely constitutes "consent" in terms of sexual activity? When can the law agree that a person has consented to sexual activity? What lines should be drawn between private sexual activity and activity that is considered assault? Ready answers to such questions do not present themselves.

I will return to the implications of the Spanner and Mark IV incidents below. I would like to first address another cluster of incidents in British and American juridico-legal history that speak to this problematic. These cases are rape and assault cases whose narratives involve sadomasochistic characters. ${ }^{46}$ But there are three important differences in the following narratives: the "sadomasochists" are heterosexual, the "sadomasochists" are women, and the "sadomasochists" are prosecuting witnesses rather than defendants. While I think that both interesting and fruitful analyses of these clusters of cases might examine the first two differences, teasing out the implications of these cases in 
terms of sexuality and gender, my focus here on the role of consent leads in the direction of the third.

\section{Consent and Coercion: The Rape Cases}

I know I had sex with her without consent. I know what I have done is wrong. I don't like myself. I've lost all my friends except those close to me.

- Rape Defendant Ben Emerson ${ }^{47}$

Despite this frank confession, Ben Emerson was awarded a verdict of "not guilty" of rape on 29 November 1994, after a two-minute jury deliberation at Leicester Crown Court. The judge commented to the jury, "I wholeheartedly agree with your verdict." The judge had actually recommended to the jury that it render a quick decision before even hearing the defense's case:

At the end of the prosecution case the judge summarized the alleged victim's evidence and reminded the jury how she and Emerson had oral sex without her objecting at her home ... the judge told the jury: "When he went to get some baby oil to massage her body, what is this young man to think when he finds in the drawer artificial penises, magazines designed to excite sexually? He finds a riding crop near her bed and chains on the bed." 48

After the trial, a friend of Emerson stated, "Justice was served in the end."49

"Justice," in this case, meant the release of a self-identified rapist because the "alleged" victim had committed the prior crime of being a pervert. There can be no doubt from the evidence that what was really on trial during this event was the prosecution witness's sexuality - the mere existence of an interest in kinky sex made her charge of rape untenable. A woman's right to say "no" to sex is here circumscribed by the discursive apparatus invoked by her sexuality - a woman with an interest in sadomasochism, rubber skirts, and body-piercing, judge and jury seem to have reasoned, cannot be raped. Her sexuality implicitly predisposes her to consent to sex - she is inscribed as always-already willing.

On 8 November 1978, an Ohio appellate court handed down a similar verdict to two men accused of rape, felonious assault, and felonious sexual penetration. The court included a detailed description of the events of 14 July 1977 in the court transcript, providing an account of victim Jane Lucas' testimony "[a]t the risk of memorializing the conduct of the Defendants for the future delight of the sexually perverse." ${ }^{50}$ This invocation of a notion of potential prurient interest in the testimony of the victim is characteristic of this court's treatment of the issues involved in this case - outright violence is sexualized 
and treated as potentially "nonserious" in the serious context of the courtroom..$^{51}$

According to Lucas' testimony, she drove to Donald Kekich's apartment with the intention of having sex with him. When they got there, Kekich told her to undress and asked if she needed to use the bathroom. In the bathroom, she was grabbed by a naked man (Howard Phillips, another of the defendants), raped, and severely beaten. Kekich and Phillips continued to rape and beat her for hours, later taking her to the apartment of other friends who joined in her torture, which lasted all night and included being threatened with a shotgun, which was then shoved inside of her while pictures were taken.

The defendants were convicted of "felonious sexual penetration", but were acquitted of rape and assault on the basis of the discursive apparatus mobilized by the following testimony: "She asked for everything. She asked to blow you, she asked to go to bed with you. I mean, every sex act that happened was through her. I mean came out of her mouth and with each and every guy." ${ }^{2}$ The appellate court vacated convictions on rape and assault charges based on testimony from a friend of Lucas' that she had overheard Lucas express masochistic fantasies, and the following birthday card sent by Lucas to Kekich, with whom she had a sexual relationship prior to the assault:

I think you're a brute, an animal and a Sex Fiend!

- And I want you to know I appreciate it!

Happy Birthday!

To a man who won't stand anything he doesn't like, do without anything he desires, or even be polite to people unless they please him.

As mean as you are - you will live a century \& then some Happy Birthday, Turkey!

Love, Janie Lucas

According to the appellate court:

It is evident in the instant case that Jane Lucas who accompanied Donald Kekich, Bruce Battista, Harold Phillips and Daniel Phillips initially by invitation got much more than she bargained for. However, it is equally obvious from evidence of record and especially from the birthday card admitted as Defendants' exhibit, supra, that had acts which followed been limited to sexual conduct it would not have been necessary to compel Jane Lucas to submit by force or threat of force and that no charges would have been filed with nothing further being heard of such occurrences.

Here the mere suggestion that Ms. Lucas might have consented without force to a sado-masochistic sexual relationship is taken as a priori evidence that she 
cannot legally be raped. Again, her sexuality inscribes her as always-already willing. The appellate court's conviction of the defendants on charges of "felonious sexual penetration" further indicates that, at least in the eyes of Ohio law, what went wrong on 14 July 1977, was not so much the violence and terror to which Ms. Lucas was subjected, but rather the introduction of a foreign object into one of her orifices - the defendants, in other words, were convicted of violating a dildo law. ${ }^{53}$

In such cases, the "sadomasochist" is seen as having given up h/er rights to protection from violence or abuse. While both cases involve heterosexual women, homosexual men as prosecution witnesses have faced similar difficulties in credibility. In August of 1993, an appellate court released a man convicted of murder because the murder victim had written a long sadomasochistic sexual fantasy in his journal and the trial court had refused this journal entry as evidence at trial. The fantasy is reproduced for the delight of the court in its entirety in the published case. The unspoken implication of the court's decision is that a man who fantasizes about homosexual sadomasochism has somehow consented to a brutal murder. The court found the journal entry "essential to the appellant's defense":

It suggested Craven may have desired to be involved, and may have been involved in voluntary sadomasochist sex when he was killed. If he suffered from these desires, then he might have sought out an amenable partner. ${ }^{54}$

This "amenable partner", it seems, killed him. Again, the law has constituted the sadomasochist as an always-already willing victim, even to the point of death.

This opinion also highlights the idea of "voluntary sadomasochistic sex" as a "desire" that one "suffers from", a common thread in much of this discourse. The official status of "perverse" desire is thus situated as a medical and psychiatric condition that places those "afflicted" beyond the protection of the law and unworthy of inclusion in "civilized" society. Ironically, this same argument is also used to discount the stated consent of S/M practitioners in cases where there is no complaining victim. Monica $\mathrm{Pa}$ notes the rhetorical function of such "pop psychology" diagnoses:

This presumed mental depravity of the "victim" by courts infantilizes, ostracizes, and derides the intelligence and agency of $S / M$ participants. It is a rhetorical strategy, rather than a genuine attempt at psychological prognosis. This rhetoric regards S/M participants presumptively irrational, and thus, not capable of a legally-cognizable response. As a result, "since few judges or jurors can imagine why anyone would do $\mathrm{S} / \mathrm{M}$, it is easy to obtain convictions and brutal sentences." Moreover, categorizing S/M sex as simply "crazy" 
abnegates the duty to consider these issues in a judicious and complex manner. ${ }^{55}$

Legal scholar Cheryl Hanna cites a number of other rape and sexual assault cases in which the complaining victim "was someone whom a jury could have found deserving of a beating, or at least not worthy of the protection of the law." 56 State $v$. Collier, for example, dealt with a pimp who raped and beat one of his prostitutes. The victim "was a prostitute and a drug addict, and arguably sexually deviant by the nature of her profession." the court would not allow consent as a defense. But such a defense was not precluded in the more recent case of People $v$. Jovanovic, in which the New York Court of Appeals let stand a decision allowing the defendant to produce evidence that the complaining witness sought an S/M relationship with him. ${ }^{58}$ In that case the victim, a college student, admitted to having consented to some $\mathrm{S} / \mathrm{M}$ activities with Jovanovic, but testified that Jovanovic continued with the activities long after she withdrew her consent. According to the victim, Jovanovic tortured her for twenty hours, refusing to respond to the "safe word" that they had negotiated before the encounter. During this time he hog-tied her, poured wax on her body, inserted batons in her rectum, choked her, and threatened to kill her. While the court held in a footnote that " $\mathrm{t}]$ here is no available defense of consent on the charge of assault," it nevertheless found that the trial court erred by not admitting into evidence emails indicating the victim's interest in sadomasochism. ${ }^{59}$

In a recent and widely publicized case in Orange County, the son of an Assistant Sheriff was accused of participating in the videotaped gang rape of an unconscious sixteen-year-old girl. ${ }^{60}$ The defendant, Gregory Haidl, was able to get a mistrial based on the defense that the victim consented to the sex and the videotaping. The jury in the case found itself "hopelessly deadlocked", with only one juror voting to convict. Despite the videotape of the sexual activity, one juror described his reluctance to convict by stressing that "the evidence was real weak... There was too much he-said, she-said."61 While the Haidl case did not focus explicitly on sadomasochism, the "perverse" nature of the complainant's sexual desire was the cornerstone of the defense's strategy. The case illustrates the power of the rhetorical framework of consent described here.

According to press reports, the video, which was confiscated by police: begins with [Jane] Doe saying she felt "so fucked up" and resisting Haidl's attempt to remove her top.... Filming resumed eight minutes later with the defendants using Doe now naked and unconscious - for sex on a garage sofa and pool table. Later on the video, they can be seen laughing, dancing and mugging for the camera as they penetrate the 
girl's vagina and anus with a Snapple bottle, juice can, lighted cigarette and pool cue. ${ }^{62}$

When the video was discovered and police found the victim, she could remember none of the sexual activities of the night. The defendants were charged with drugging her and gang-raping her for the video.

At trial, defense attorney Joseph G. Cavallo called Doe "a 'slut' who 'craved' gang-bang sex, was 'proud' of her promiscuity, dreamed of becoming a porn star and actually directed the sexual encounter with the defendants while she 'feigned' unconsciousness." 63 Another defense attorney argued that there was "consent from beginning to end, from start to finish." 64 The theory supported by the defense was that it was Doe, rather than Haidl, who initiated the events, and that despite the drugs in her system she was faking unconsciousness in order to fulfill her dream of starring in a "prearranged, necrophiliathemed porno." 65 Reporter Scott Moxley, who covered the case extensively for the Orange County Weekly, noted that the defense strategy in the case depended upon them trying to "convince at least one of 12 Orange County jurors that men aren't responsible for sex when they think an unconscious, underage girl really, really wants it." 66 In fact, they were able to convince eleven of them.

In each of the above cases, the court legitimized a defense of "consent" as used against complaining victims of sexual and physical assault. Yet in Spanner and similar cases ${ }^{67}$ the court overruled this defense where there is no complaining victim. The implication common to both sets of circumstances is that the public image of the "sadomasochist" as established by legal and psychiatric tradition will be imposed upon the "victim" even where there is no identifiable complainant who falls into this category. Where there is a victim, $\mathrm{h} / \mathrm{er}$ voice will be silenced and replaced by this public image. S/he will be stripped of the legal privilege to say "no" to unwanted sexual attention, assault, kidnapping, and even murder. And where there is no victim, this public image will create a hypothetical victim who is then stripped of the mental or emotional capacity to say "yes".

The irony here is that juridico-legal traditions are willing to impute consent to someone who claims not to have granted consent, while those same traditions are unwilling to recognize consent when the "victim" claims to have granted it. These traditions hold that a crime has occurred when there is no complaining victim, yet when there is a complaining victim these same traditions will declare, over $h /$ er objections, that $s / h e$ was asking for it. In either case the "pervert" is presumed to be incapable of knowing his or her own subjectivity.

This presumption of ignorance - and not just ignorance but of the lack of the very capacity to know oneself - is a common theme in many of these cases. In the 1967 assault case People v. Samuels, for example, a California appellate court convicted the defendant on the basis of a film of him whipping another 
man. Samuels raised a consent defense which was rejected on the argument that it was not possible for a defendant to consent to the kind of behavior witnessed on the film. "[C]onsent of the victim," the court held, "is not generally a defense to assault or battery, except in a situation involving ordinary physical contact or blows incident to sports such as football, boxing or wrestling." The court continued, "It is a matter of common knowledge that a normal person in full possession of his mental faculties does not freely consent to the use, upon himself, of force likely to produce great bodily injury." 68 Gayle Rubin has criticized this case, looking at the implications of this logic:

[A]nyone who would consent to a whipping would be presumed non compos mentis and legally incapable of consenting. S/M sex generally involves a much lower level of force than the average football game, and results in far fewer injuries than most sports. But the court ruled that football players are sane, whereas masochists are not. ${ }^{69}$

Here, as elsewhere, the "pervert" is presumed to be legally incapable of consent. This presumption has profound implications for subjectivity. The voiceconsciousness of the subject is effaced by the legal logic at work.

This logic is laid out even more explicitly in a more recent case in Massachusetts. Alden Baker of Middlesex was charged in 2001 with being a "Sexually Dangerous Person" (SDP) for practicing S/M with consenting partners. The state SDP law calls for involuntary imprisonment of people who "suffer from a 'mental abnormality' that makes them likely to commit future sex offenses." The jury heard expert testimony, some of which claimed that the mere participation in consensual S/M activities rendered the defendant "clinically deviant." 70 The jury eventually found that the Commonwealth had not met its burden of proof, and released the defendant. ${ }^{71}$ While Baker thus avoided prison, the way in which the question of "mental abnormality" was raised suggests that the figure of the "gay slave" as incapable of consent still animates contemporary legal discourse.

\section{Consent and Erotic Subjectivity: Concluding Thoughts}

Early on in this essay, I suggested a bifurcated psychoanalytic reading of the sentence "police free gay slaves". Like Freud's sentence "a child is being beaten," the sentence produced by the Orange County Register has a dual origin: one in the specific circumstances of the Mark IV raid (or any such event), and the other in the larger discursive formation that is produced through the history of the relationship between law, sexuality, and consent. One might argue more generally that the relationship here is between the discursive formation and the constitution of an individual (perverted) subjectivity. 
In the Mark IV incident, the figure of the "gay slave" to be "freed" by police is mobilized to speak in the place of actual participants in the events under public scrutiny. A strict interpretation of this figure calls to mind the photographs the LAPD made available to the Associated Press after the raid Val Martin, in the interview cited above, recalls that during the raid the police had chosen for arrest

the ones who were the most outrageous, because everyone who was in jail with me were, like, in leather chaps and nothing else, the rest of the body was nude. You know, pierced tits, chains, really the way we really dress for an evening like that.

Martin stressed the performative nature of the figure at work here, whereas the police and media representations take the figure quite literally, characterizing the "sadomasochist" as one who enjoys and deserves $\mathrm{h} / \mathrm{er}$ political repression, whether it operates through legal or extralegal machanisms, and even to the point of death. ${ }^{72}$ This figure is recognizable more broadly as a marginal but visible figure in popular culture (witness the popularity of movies like The Secretary, Pulp Fiction, and Body of Evidence) and in psychiatry and psychoanalysis (see, for example, Krafft-Ebing's meticulously documented case histories) as well as in law and politics.

This implies a rhetorical understanding of the trope of the "gay slave" or, more generally, the sadomasochistic "pervert." Obviously, the monolithic nature of this trope tells us nothing about the actual sexual practices and roles involved in leather and $\mathbf{S} / \mathbf{M}$ sexual identities. The rich diversity of sexualities potentially encompassed by this category is flattened out by the popular image of the "gay slave." While the figure as mobilized in the Mark IV raid was gendered male, I would suggest that the more general figure at work in this discourse is not gendered male or female per se, but is more precisely gendered as always-already in drag. Like drag, S/M is not just a sexual practice but also a mode of performance art. The costumes, the uniforms, the props, the meticulous attention to setting a stage and following a script, these all point to a consciousness among participants of the performativity of sadomasochistic sexual practices. As Monica Pa notes, "S/M is not so much a 'replay' of violent interactions as it is a self-consciously transmogrified parody." 73

What is at stake in the mobilization of this trope (and of the more general image of the "sadomasochist" to which the trope refers) in the context of the Mark IV raid is not so much any particular sexual "identity" as such, but rather the unknown and unknowable threat to the public posed by what the trope is presumed to represent. The "gay slave" is always "in drag" because s/he performs a sexuality that marks something irreducibly other. This irreducible otherness is always ultimately associated with death. Pat Califia addressed this trope as it appears in the book Modern Primitives: 
There are so many things wrong with this breezy little stereotype that it's hard to know where to begin to deconstruct it.... [The] linking of power-exchange sex to thanatos is nothing but a cliché. Our community is interesting (and powerful) precisely because we have chosen to live, to fashion relationships, organizations, institutions, traditions, mythology, and norms - in spite of all the voices from outside which tell us we (a) are obsessed with death and (b) deserve to die. ${ }^{74}$

Although Califia speaks here to a very different context for the use of this figure, its characteristics differ little from those mobilized in the juridico-legal realm discussed above. In spite of ubiquitous evidence that the "sadomasochist" engages in often complex and multifaceted rituals of staging sexuality - and that these rituals hold various meanings for different participants the dominant social discourse must incessantly reduce these meanings to a relationship with death that is both descriptive and normative. This relationship has substantive political implications for the ways in which sexuality is treated in a given society. The assumed relation between sadomasochism and death gives way to another assumption, also spelled out by Califia:

we must enjoy being oppressed and mistreated. We like to wear uniforms? Then we must get off on having cops bust up our bars. We like to play with whips and nipple clamps and hot wax? Then it must turn us on when gangs of kids hunt us down, harass and beat us. We're not really human. We're just a bunch of leather jackets and spike heels, a bunch of post office boxes at the ends of sex ads. ${ }^{75}$

The exercise of power (whether it be the legitimized power of the state or the illicit power of extralegal repressions such as police harassment, queer-bashing, and public humiliation) against the "sadomasochist" is here legitimized as something inevitable, necessary, and even "enjoyable" to the objects of such power.

I argued earlier that the sentence "police free gay slaves" predicates a history of repression. Most of the above analysis has been directed at one aspect of that history, the discursive history of the relationship of the law to "sadomasochism." What have been repressed throughout this discursive history are the specific mechanisms by which the erotic subjectivity I have perhaps oversimplistically designated by the name "gay slave" is produced by a dominant discourse. Another aspect of the history of repression predicated in the sentence is of course the set of material events surrounding the Mark IV raid, and indeed, the specific nature of any such event. Materially, the "freedom" police provided the "gay slaves" involved handcuffing them, arresting them, photographing them, taunting them, subjecting them to verbal abuse, denying them the right to use the toilet, then forcing them through a long and expensive pub- 


\section{Attias}

licized legal process which ruined many families and careers. This trope, then, is primarily a vehicle for the exercise of power. In order for that power to be effectively exercised, it is essential that the sadomasochist keep quiet. The decision to say "yes" or "no" to sexual activity is one best left up to judge and jury rather than participant.

Finally, I think it important to add that events such as Spanner and the Mark IV raid also helped alter the meaning of the trope of the "gay slave" in public discourse in progressive ways. ${ }^{76}$ Foucault's notion of resistance as "the odd term in relations of power" 77 is particularly relevant here; Foucault writes: "Discourse transmits and produces power; it reinforces it, but also undermines and exposes it, renders it fragile and makes it possible to thwart it."78 Foucault shows how the production of discourse about perversity in general and homosexuality in particular produced a whole array of mechanisms of social control and domination. At the same time, however, the introduction of this category of personality

made possible the formulation of a 'reverse' discourse: homosexuality began to speak in its own behalf, to demand that its legitimacy or 'naturality' be acknowledged, often in the same vocabulary, using the same categories by which it was medically disqualified. ${ }^{79}$

Similarly, I would argue that the production of the category of the "gay slave" in Los Angeles in 1976 helped allow this figure to begin to speak on its own behalf. The Mark IV incident was, in fact, a political disaster for the LAPD. "Gay" and "straight" publics alike saw the raid as a waste of precious resources that should have been spent fighting real crime. ${ }^{80}$ As if to dramatize the sense of public priorities that was affronted by the LAPD's overzealous actions, a woman was mugged and murdered just ten blocks from the Mark IV while the raid was going on. ${ }^{81}$ One hundred and seven cops to bust a charity ball but not a single one to save a woman's life - needless to say, this image did not play well to a California public that had just passed a gay rights ordinance but was jittery about street crime. The District and City Attorneys immediately dissociated themselves from the LAPD's position until the prosecution dropped the ridiculous "slavery" charges, and the City received hundreds of letters from the public protesting the raid. ${ }^{82}$

The raid and its aftermath have been compared to the Stonewall riots because "we learned how to cope with it, fight back, stand up for our rights". ${ }^{83}$ While Stonewall stands as the privileged figure of gay resistance in history, the Mark IV Slave Auction constitutes a less visible historical moment. It is a moment in which the struggle over the meaning to be assigned the trope "gay slave" was temporarily won by those most frequently subjected to the powereffects of this trope. Martin recalls that after the Mark IV raid: 
There is more unity; when people began to find out what was really going on, what the image of a leather person was, that a lot of people had a wrong idea of the leather community. When people in the gay community find out what we are really like, they change their minds about us. They fuss, of course, but we are more respected. ${ }^{84}$

This respect was an important outcome of the struggle over the meaning of the "gay slave" trope.

But this respect has come at a price. The Mark IV raid took place during a period of frequent attacks by the LAPD against the leather and S/M communities, ${ }^{85}$ and the negative publicity the LAPD received as a result of the raid did not put much of a damper on its use of legal and extralegal means to attack leather bars. In one incident just a few months after the Mark IV auction, for example, Long Beach police visited another "slave auction" benefit. Over two weeks after their visit, the officers arrested three gay men for their participation in the auction. ${ }^{86}$ On Valentine's Day, 1992, eleven LAPD officers raided the Dragon House (a "gay sex club") without a warrant and seized the club's membership information and money that had been raised to benefit a hospice. ${ }^{87}$

In a more recent, and more widely publicized, incident, police in the small town of Attleboro, Massachusetts raided a private $\mathrm{S} / \mathrm{M}$ club that that they were surprised to discover right across the street from the police station. ${ }^{88}$ Prostitution charges were brought against the owner of the property and a woman at the club faced assault charges "for allegedly spanking a woman's bare bottom until it bled, using a wooden paddle." 89 The response of the fetish community to the raid illustrates Foucault's notion of resistance well. The police raid was quickly dubbed "Paddleboro" by activists who raised money for a legal defense fund and drew attention to the raid as a discriminatory attack against a group of erotic dissidents. The American Civil Liberties Union and the National Coalition for Sexual Freedom joined the fight against the prosecutions, and the raid was widely criticized in the press. One reporter noted that the Paddleboro case was "quickly becoming a smaller version of the famous 1969 Stonewall raid in Greenwich Village that sparked the modern gay rights movement." $90 \mathrm{~S} / \mathrm{M}$ activists, energized by the public attention to the raid, have developed seminars and guidelines to help police understand when behavior that appears unusual is part of "safe, sane, and consensual" S/M activity. ${ }^{91}$ The charges were dropped in $2001 . .^{92}$

The Mark IV incident described in this essay is all but forgotten even among Los Angeles-area gay activists, and it is rarely mentioned in gay history books. ${ }^{93}$ Spanner, on the other hand, has had much more visibility, even in mainstream European historical analyses. When the Spanner defendants were first convicted, a British S/M community rallied to their defense, and outspoken voices criticized the European Court of Human Rights decision upholding 
the British courts. ${ }^{94}$ Commentators attributed to Spanner a "sea change" in attitude about fetishism and sadomasochism. ${ }^{95}$ The legal conclusion of the Spanner case was the criminalization of S/M sexual conduct as assault, but the social reaction to the case again illustrated the complex relationship between power and resistance. Spanner helped bring attention and even social acceptability to $\mathrm{S} / \mathrm{M}$ practices in Europe.

The lack of attention among historians to the Mark IV incident is decidedly unfortunate, for, like Spanner, the incident marks a significant turning point in the struggles for sexual liberation - not because it loosened juridicolegal controls on sexuality directly, but rather because the political fallout from the raid set the social stage for public sympathy for gays as victims of harassment. The idea that consensual sexual activity could be criminalized was briefly exposed as legalized harassment. While the harassment would continue, the social conditions of its legitimacy had begun to deteriorate. ${ }^{96}$

I am grateful to the many readers this piece has had in the years since I began working on it. In particular I would like to thank Carole Blair, Donald E. Hall, and Gayle S. Rubin for their comments on previous drafts and for their strong encouragement of this project. I am also grateful to the editors of Left History for their patient editorial guidance.

\section{Notes}

${ }^{1}$ See Clare Dyer and John Carvel, "Jailed Gays Win Right to Europe Case," The Guardian, 19 January 1995, 5; "Rights Body Hears Sado-masochists' Complaint Against Britain," Agence France Presse, 18 January 1995; Geoff Meade, "Jailed SadoMasochists Get Euro-Court Appeal," Press Association Newsfile, 18 January 1995, Home News Section. The case was Laskey, Jaggard, and Brown v. The United Kingdom (109/1995/615/703-705), decided on 19 February 1997. The full text of the court's judgment is available online at http://perso.wanadoo.fr/paul.bailey/spanjudg.txt.

${ }^{2}$ Nick Cohen, "Case Redefines What Consenting Adults Can Do," The Independent, 20 December 1990, 8.

${ }^{3}$ Barry Beelzebub, “The Devil's Advocate," Bristol Evening Post, 8 January 2003, 6. Three of the sixteen men filed suit in the Court of Human Rights.

${ }^{4}$ The videotapes were discovered accidentally in a private collection by police and prosecution was brought solely on the basis of the tapes.

${ }^{5}$ Clare Dyer, "Sado-Masochists" Appeal Fails in Landmark Court Ruling," Manchester Guardian Weekly, 2 March 1997, 9; see also Patricia Wynn Davies, "Europe Gives S\&M Stamp of Disapproval," The Independent, 20 February 1997, 5; and Anne Johnstone, "Lessons in the School of Hard Knocks," Glasgow Herald, 20 February $1997,15$. 
6 Paul Bailey, "Operation Spanner," published online at http://perso.wanadoo.fr/paul. bailey/spanner.htm.

${ }^{7}$ When the Spanner case was heard in the House of Lords, Lord Lowry, who found with the majority, pointed out that "every submission put forward on behalf of the appellants" presumed that "to place a restriction on sado-masochism is an unwarranted interference with the private life and activities of persons who are indulging in a lawful pursuit and are doing no harm to anyone except, possibly, themselves." Regina v. Brown House of Lords, 1 AC 212 (1994; decided 11 March 1993) Judgment 3. For Lord Lowry, this argument assumed the legality and relative harmlessness of consensual sado-masochistic activity, both assumptions that he found incorrect. Lord Mustill, who dissented from the majority judgment, likewise illustrated the centrality of the civil libertarian argument when he stressed that the case "should be a case about the criminal law of private sexual relations, if about anything at all" (Judgment 4).

${ }^{8}$ While a comprehensive discursive history of sexuality and the law does not, to my knowledge, exist, several scholars have made inroads into this general area, collecting diverse pieces of such a history. Studies such as Roger Davidson, "This Pernicious Delusion': Law, Medicine, and Child Sexual Abuse in Early-Twentieth-Century Scotland," Journal of the History of Sexuality 10, 1 (January 2001); Pat Califia, "The Age of Consent: The Great Kiddy-Porn Panic of '77" and "The Aftermath of the Great Kiddy-Porn Panic of '77" in Public Sex: The Culture of Radical Sex (Pittsburgh: Cleis Press, 1994), and Leslie Moran, "Buggery and the Tradition of Law," New Formations: A Journal of Culture/Theory/Politics 19 (Spring 1993), for example, are important case studies within an emergent field of scholarship at the intersections of the study of sexuality, the law, and discursive history. I see Gayle Rubin's "Thinking Sex: Notes for a Radical Theory of the Politics of Sexuality," in The Lesbian and Gay Studies Reader, ed. Henry Abelove, et al. (London: Routledge, 1993) as underlining the necessity of such scholarship, however piecemeal and incomplete, particularly at historical moments of moral panic.

${ }^{9}$ I should add that the various case studies I have chosen span almost three decades and two continents. I do not wish to claim that these incidents are completely representative of that time period or of what I perhaps too simplistically call the "Anglo-American legal tradition", nor do I wish to gloss over significant differences between the British and American legal contexts. More careful analysis of such differences could be the basis for a project in its own right.

${ }^{10}$ Susan Fraker and John Barnes, "California: Of Human Bondage," Newsweek, 26 April 1976, 35; "Mark IV Raid Receives Wide News Coverage Across Nation," NewsWest, 30 April - 14 May, 1976; and "107 Officers Used in Mark IV Raid, Police Papers Reveal," NewsWest, 25 June 1976.

11 "107 Officers," 41 . According to this piece, there were only 119 people in the building at the time of the raid. 
${ }^{12}$ Olaf Odegaard, "Knights in Black Leather: Part II - The Great Slave Auction Bust (An Interview With Val Martin)," Autumn 1984, for The Connection (unpublished ms.) 13 "Mark IV Raid Receives Wide Coverage."

${ }^{14}$ Val Martin recalls: "The cop just freaked out. The other people had pierced tits and everything and for the cops it was like a carnival. They must have called everybody in the building to come in and take a look at us. They were taking pictures, calling us names..." Odegaard, "Knights in Black Leather."

${ }^{15}$ In doing so, she was perhaps only following Quintilian, who defended abusio as a means of adapting existing words to new meanings; see Institutio Oratio VIII 6:34-6.

${ }^{16}$ Gayatri Chakravorty Spivak, "Can the Subaltern Speak?" in Marxism and the Interpretation of Culture, ed. Lawrence Grossberg and Cary Nelson (Urbana, IL: University of Illinois, 1988), 296-7; see Sigmund Freud, “'A Child Is Being Beaten': A Contribution to the Study of the Origin of Sexual Perversions," (1919) in Collected Papers vol. 2, trans. Alix and James Strachey (London: Hogarth, 1956), 172-201. Interestingly, Freud's account turns on the specific phrasing of the sentence; for Freud, the child goes through three stages in relation to the fantasy of child-beating, and each phase is expressed through a different sentence. Phase One: "My father is beating the child", phase two: "I am being beaten by my father", and phase three: "a child is being beaten". At stake in this grammatical movement seems to be the gradual disappearance of the acting and speaking subject.

${ }^{17}$ Spivak's essay animates the present study in ways that go beyond her method of reading a particular rhetorical figure. While my analysis bears little resemblance to hers, I am nonetheless particularly indebted to her method of historical narration.

${ }^{18}$ Michel Foucault, The History of Sexuality: An Introduction, trans. Robert Hurley (New York: Vintage, 1978), 45-9.

${ }^{19}$ Ibid., 47.

20 "Foucault makes it abundantly clear that he is not denying the existence of sexual repression so much as inscribing it within a large dynamic. Sexuality in Western societies has been structured within an extremely punitive social framework, and has been subjected to very real formal and informal controls. It is necessary to recognize repressive phenomena without resorting to the essentialist assumptions of the language of libido. It is important to hold repressive sexual practices in focus, even while situating them within a different totality and a more refined terminology" (Rubin, "Thinking Sex," 10).

${ }^{21}$ Michel Foucault, Abnormal: Lectures at the Collège de France, 1974-1975, trans. Graham Burchell (New York: Picador, 2003), 48.

${ }^{22}$ Foucault, History of Sexuality, 72.

${ }^{23}$ Justice Scalia's dissent in Lawrence $v$. Texas, examined below, rather self-consciously adopted the language of this moral panic when he castigated lawyers who supported "the so-called homosexual agenda, by which I mean the agenda promoted by some homosexual activists directed at eliminating the moral opprobrium that has traditionally attached to homosexual conduct." 
${ }^{24}$ I am using the phrase "moral panic" in the sense established by Jeffery Weeks and Gayle Rubin in their work on sexuality; see Rubin, "Thinking Sex," and Jeffery Weeks, Sex, Politics, and Society: The Regulation of Sexuality Since 1800 (New York: Longman, 1981). Both Weeks and Rubin build on the notion as developed by Stanley Cohen in 1972: "Societies appear to be subject, every now and then, to periods of moral panic. A condition, episode, person or group of persons emerges to become defined as a threat to societal values and interests; its nature is presented in a stylized and stereotypical fashion by the mass media; the moral barricades are manned by editors, bishops, politicians, and other right-thinking people; socially accredited experts pronounce their diagnoses and solutions; ways of coping are evolved or (more often) resorted to;... Sometimes the panic is passed over and is forgotten, except in folklore and collective memory; at other times it has more serious and long-lasting repercussions and might produce such changes as those in legal and social policy or even in the way society conceives itself." Stanley Cohen, Folk Devils and Moral Panics: The Creation of the Mods and Rockers (London: MacGibbon and Kee, 1972), 28.

${ }^{25}$ One is tempted to read the Clinton impeachment hearings as a bizarre footnote to this moral panic.

${ }^{26}$ See Harry Denny, “( $(\mathrm{Re})$ figuring Homosexuality, 'Real Minorities' and Civil Rights: A Textual Analysis of Colorado for Family Values' Amendment Two Tabloid," Cultural Studies: A Research Annual 2 (1997), 129-141.

27 The US Supreme Court's decision in Romer v. Evans, which declared illegal Colorado's voter initiative eliminating any laws protecting classes of people based on sexual orientation, marks an important turning point in the court's treatment of such issues. Justice Kennedy's majority opinion makes clear that laws "born of animosity" towards a particular social class will not be tolerated. Majority opinion, Romer v. Evans (517 US 620, 1996); available online at http://supct.law.cornell.edu/supct/html/941039.ZO.html.

${ }^{28}$ Rubin, "Thinking Sex," 25.

${ }^{29}$ The anti-slavery law, of course, was a relic of post-Reconstruction America, and was never intended to be used to break up consensual social or sexual activities. There is little question that the social meaning of sadomasochistic sexual practice in the United States is marked by the historical memory of actual slavery. While an investigation of the history of the notion of "slavery" in America that connects the African slave trade and the "white slave" panic of the early twentieth century to notions of sexual slavery that have become an increasingly visible aspect of American popular culture is well outside of the scope of this study, it is worth noting here that the American S/M experience in particular is rife with as-yet-unexamined racial and political meaning that may be missing from the British context. (In the British context, by contrast, one would do well to focus not so much on the racial meaning of sexual "slavery" as on its relation to class anxiety.)

${ }^{30}$ Cited in "Mark IV Raid Receives Wide News Coverage Across Nation." 
${ }^{31}$ Regina v. Brown, House of Lords, 1 AC 212 (1994; decided 11 March 1993) Judgment 1.

${ }^{32}$ Regina v. Brown, Judgment 2.

${ }^{33}$ But see Lord Mustill's dissenting opinion, in which he systematically compares consent in S/M sex cases to other cases where consensual violence is involved, including sports, prize fighting, and elective surgery.

${ }^{34}$ Monica $\mathrm{Pa}$, "Beyond the Pleasure Principle: The Criminalization of Consensual Sadomasochistic Sex," Texas Journal of Women \& the Law 11 (Fall 2001), 74-5.

${ }^{35}$ Sangeetha Chandra-Shekeran, "Theorizing the Limits of the "Sadomasochistic Homosexual' Identity in R. v. Brown," Melbourne University Law Review 21 (1997), quoted in $\mathrm{Pa}$, "Beyond the Pleasure Principle," 75. See also the discussion in Bill Thompson, Sadomasochism: Painful Perversion or Pleasurable Play? (New York: Cassell, 1994), esp. Chapter 7.

${ }^{36}$ In Commomwealth v. Appleby, for example, the Massachusetts Supreme Court handed down a ten-year sentence to a defendant for beating his sexual partner with a riding crop. The sentence was enhanced because the crop was treated as a dangerous weapon "capable of being used to inflict serious bodily harm, and possibly even death" (402 N.E.2d 1057, 1980). Pa points out that there was no "explanation as to how someone could be killed with a riding crop" ("Beyond the Pleasure Principle," 72). In a recent case in Nebraska, Roger Van was sentenced to 30 years after pleading guilty to kidnapping and torturing a man in his basement during an S/M encounter that appears from the evidence to have started out consensual. See "Wayne Man Gets up to 30 Years for SexTorture Case," Associated Press, 5 September 2003. It is notable that the victim in the Roger Van case "testified that he had not required medical attention when he returned to Houston, and no evidence was introduced about any actual injuries." Arthur S. Leonard, "Master Faces 85 Years in Prison; Consent Defense Ruled Out," Gay City News, 26 July 2002, available online at http://www.gaycitynews.com/GCN9/ SMScene.html.

${ }^{37}$ Lawrence and Garner v. Texas (539 US 558, decided 26 June 2003), overturning Bowers v. Hardwick (478 US 186, 1986).

${ }^{38}$ Bruce Steele, "Having the Last Laugh," The Advocate, 19 August 2003, available online at http://www.advocate.com/html/stories/895_6/895_6_steele.asp.

${ }^{39}$ Justice Scalia, dissenting opinion, Lawrence and Garner v. Texas, available online at http:/supct.law.cornell.edu/supct/html/02-102.ZD.html.

${ }^{40}$ Including, notably, obscenity. Scalia, in spite of his trumpeting of free speech concerns in cases such as R.A.V. v. City of St. Paul (505 US 377, 1992), has always been particularly resistant to any narrowing of the scope of obscenity laws, as seen for example in his dissenting opinion in US v. Playboy Entertainment Group (30 F. Supp. 2d 702, 2000).

${ }^{41}$ Scalia, dissenting opinion, Lawrence and Garner v. Texas. One journalist took this logic even further: "Scalia, Santorum, and their allies are really concerned about the right of legislatures to regulate so-called victimless crimes: drug use, suicide, neglect- 
ing to wear a seatbelt, or even - as Robert P. George, a professor of jurisprudence at Princeton, is fond of suggesting - 'consensual cannibalism'." Christopher Shea, "An Amoral Court?" Boston Globe Online, 20 July 2003, available online at http://www.boston.com/dailyglobe2/201/focus/An_amoral_court_+.shtml. It is clear that this "slippery slope" argument, often carried to absurd extremes, has been mobilized by a host of critics of the decision. The following, for example, was published in the Catholic Herald: "What case will be next? Incest, bigamy, homosexual marriages, sadomasochistic conduct, and so on, all fit within the scope of this extraordinary opinion which follows a line of thinking about freedom and 'privacy' that spawned Roe $v$. Wade. The Lawrence opinion is another generated by judicially undisciplined justices whose personal morals are outraged by a citizenry with a differing sense of morality." Mary S. Mead, "Lawrence v. Texas: Freedom for What?" Catholic Herald, 10 July 2003, available online at http://www.catholicherald.com/articles/03articles/ meade0710.htm.

${ }^{42}$ Scalia portrays Bowers as the last barrier between civilization and barbarism; overturning it, from his perspective, represents a rejection of the possibility of any laws against "victimless" moral crimes. But why place Bowers in this privileged position, instead of, say, Romer v. Evans or even Roe v. Wade? Even for one who shares Scalia's view of what constitutes barbarism (which I do not), any decision or policy, pre- or post-Bowers, that liberalized the individual's expectation of privacy could be interpreted as the beginning of the slippery slope. Scalia cites " $[t]$ he impossibility of distinguishing homosexuality from other traditional 'morals' offenses" as the reason for its privileged placement, but this is nonsense - one could readily say the same about obscenity, gambling, prostitution, recreational drug use, etc. If it is impossible to distinguish homosexual behavior from gambling, then there is no basis for making Bowers the litmus test for the constitutionality of morals legislation.

${ }^{43}$ It should be added that Scalia's position rather disingenuously presumes a mutually exclusive dichotomy between the state's right and the individual's. Scalia presumes that constitutionally recognizing private consensual activity as a fundamental right would make it impossible to regulate that activity. Constitutional protection would certainly raise the threshold for regulation, but, as Scalia is well aware, it would not render all such regulation unconstitutional.

44 Justice Kennedy, majority opinion, Lawrence and Garner v. Texas, available online at http://supct.law.cornell.edu/supct/html/02-102.ZO.html.

${ }^{45}$ Clarence Thomas, dissenting opinion, Lawrence and Garner v. Texas, available online at http://supct.law.cornell.edu/supct/html/02-102.ZD1.html. Other conservative voices can afford to be much more direct; for example, Robert P. George: "not only sodomy, but also fornication, adultery (e.g., spouse swapping, 'swinging'), polygamy, group sex, prostitution, adult brother-sister or parent-child incest, and (depending on one's views about the rights of animals and their capacity to consent) bestiality are protected as specifications of the constitutional right of privacy. All of these acts and practices are, or can be, consensual. If consent provides the standard of inclusion within the 
right of privacy, they must all be admitted." Robert P. George, "Rick Santorum Is Right," National Review Online, 27 May 2003, http://www.nationalreview.com/comment/comment-george052703.asp.

${ }^{46}$ Unlike Spanner and the Mark IV raid, I do not present these cases as defining moments in the history of "perverse" sexuality. I also do not present them as representative of rape cases in general. Rather, I offer them as symptomatic of a particular way of understanding consent in relation to sexual activity.

${ }^{47}$ Ben Emerson, quoted in "Student Cleared in Body-Piercing Rape Case," Press Association Newsfile, 30 November 1994; see also Aubrey Chalmers, "Rape-case Girl 'Had Handcuffs and a Whip'," London Daily Mail, 30 November 1994, 29.

${ }^{48}$ Quoted in "Student Cleared in Body-Piercing Rape Case."

${ }^{49}$ Ibid.

${ }^{50}$ State v. Battista, Court of Appeals of Ohio, Fifth Appellate District, Stark County, Ohio, Slip Opinion (1978 Ohio App. LEXIS 11037, decided 8 November 1978).

${ }^{51}$ I am thinking here of Derrida's playful deconstruction of these categories in Jacques Derrida, Limited Inc. (Evanston, IL: Northwestern University Press, 1989). Monica Pa points out that this move is a typical ritual of $\mathrm{S} / \mathrm{M}$ trials that marks them as public confessions. "The irony in this," she writes, "is that the court stages a public spectacle, proliferating and acknowledging the very conduct the juridical domain seeks to isolate and punish" ("Beyond the Pleasure Principle," n135).

${ }^{52}$ Testimony of Bruce Battista, State v. Battista.

${ }^{53}$ The relevant portion of the statute states as follows: "No person without privilege to do so [it is unclear who has this privilege] shall insert any instrument, apparatus, or object into the vaginal or anal cavity of another, not the spouse of the offender, when any of the following apply: (1) The offender purposely compels the other person to submit by force or threat of force..." Section 2907.12, Ohio Revised Code, Felonious Sexual Penetration, cited in State v. Battista.

${ }^{54}$ Leitner v. State (1983) 631 So. 2d 278-9.

${ }^{55} \mathrm{~Pa}$, "Beyond the Pleasure Principle," 76.

${ }^{56}$ Cheryl Hanna, "Sex Is Not a Sport: Consent and Violence in Criminal Law," Boston College Law Review 42 (March 2001), 272.

${ }^{57}$ Ibid., 272; see State v. Collier (372 N.W.2d 303, 1985).

${ }^{58}$ People v. Jovanovic (263 A.D.2d 182, 1999).

${ }^{59}$ The emails were not necessary to establish that the victim had agreed to an $\mathrm{S} / \mathrm{M}$ encounter with the defendant, which she had admitted in open court. Rather, the defense wanted them entered into evidence unredacted in order to establish that she had consented (or that Jovanovic could reasonably believe that she had consented) to all of the activity that took place. In redacting the emails, the trial court "prevented Jovanovic from presenting the viable defense that the complainant had reason to fabricate the nonconsensual and violent elements of her story," People v. Jovanovic (263 A.D.2d 199, 1999). 
${ }^{60}$ Chelsea J. Carter, "Teens Charged with Gang Rape Caught on Videotape," Associated Press, 12 July 2002.

${ }^{61}$ Claire Luna, Stuart Pfeifer, and Mai Tran, "Gang-Rape Case Ends in Mistrial," Los Angeles Times, 29 June 2004, B1.

${ }^{62}$ R. Scott Moxley, "Mean Girls," LA Weekly, 4-10 June 2004, available online at http://www.laweekly.com/ink/04/28/news-moxley.php.

${ }^{63}$ R. Scott Moxley, "Raped Again?” Orange County Weekly, 26 March - 1 April 2004, available online at http://www.ocweekly.com/ink/04/29/news-moxley.php.

${ }^{64}$ John Barnett, quoted in Claire Luna, "Alleged O.C. Gang-Rape Victim Testifies," Los Angeles Times, 19 May 2004, B1.

${ }^{65}$ R. Scott Moxley, "Justice Takes a Pool Cue," Orange County Weekly, 9-15 July 2004, available online at http://www.laweekly.com/ink/04/33/news-moxley.php.

${ }^{66}$ Moxley, "Raped Again?"

${ }^{67}$ I am implicitly arguing here for the similarities between Spanner and the Mark IV raid; however, there are important distinctions to be made between the two as well. In particular, the Mark IV defendants were never charged with assault; the outrageous charge of "slavery" was quickly changed to a felony charge of "pandering". This charge too was dropped against all but four of the 40 defendants, who plea-bargained to misdemeanor pandering charges. So "consent" was in fact never an explicit issue in the Mark IV case. But the issue of "consent", as argued above, was certainly implicated by the characterization of the benefit's participants as "gay slaves".

${ }^{68}$ People v. Samuels (250 Cal. App. 2d 501, 513-14; 58 Cal. Rptr.439, 447).

${ }^{69}$ Rubin, "Thinking Sex," 31.

${ }^{70}$ Harvey A. Silverglate and Carl Takei, "Commonwealth v. Baker Poses Novel Question," Massachusetts Lawyers Weekly, 24 February 2003, 11.

${ }^{71}$ Commonwealth of Massachusetts v. Alden Baker, Superior Court of Massachusetts Civil Action No. 01-2147 (3 April 2003).

72 This was of course the status of the court's reasoning in Leitner $v$. State that the victim had been murdered as a result of a sadomasochistic fantasy carried to its "logical extreme". Additionally, the Mark IV raid was later rationalized by Deputy Assistant Attorney Robert $\mathrm{N}$. Jorgensen as part of a murder investigation: "This slave auction appeared to be associated, in the opinion of some police officers, with certain murders in which there were dismemberments." in "Orange County Torso Murders Reportedly Reason for LAPD Raid," NewsWest, 11-25 June 1976, 6. Of course, no such "associations" were ever spelled out by LAPD spokespersons, nor did anyone make clear how an investigation into murders in Orange County led police to a Hollywood bath house.

${ }^{73} \mathrm{~Pa}$, "Beyond the Pleasure Principle," 78.

${ }^{74}$ Califia, "Modern Primitives, Latex Shamans, and Ritual S/M," Public Sex, 233.

${ }^{75}$ Califia, "Feminism and Sadomasochism," Public Sex, 174

${ }^{76}$ I cannot, unfortunately, say the same about the rape cases discussed here.

${ }^{77}$ Foucault, History of Sexuality, 96.

${ }^{78}$ Ibid., 101. 


\section{$82 \quad$ Attias}

${ }^{79}$ Ibid., 101-2.

${ }^{80}$ There were six letters to the Los Angeles Times protesting the raid, 16 April 1976, and the coverage the raid received nationally was generally unsympathetic to the LAPD.

${ }^{81}$ Odegaard, "Knights in Black Leather ... (Interview with Val Martin)."

${ }^{82} \mathrm{Ibid}$. Val Martin tells the interviewer, "it was in the papers, on the news, on TV, radio, they started talking about that, slavery, and people started laughing. They started sending letters to the police department protesting, from the community, including a lot of straight people, so they changed the charges from slavery to prostitution."

${ }^{83}$ Ibid.

${ }^{84}$ Ibid.

${ }^{85}$ Joseph Bean, personal communication, 22 January 1995.

86 "Another Slave Auction Bust," NewsWest, 1 October 1976.

${ }^{87}$ Jeff Clark, "New Sex Club Raids," Vanguard, 6 March 1992.

${ }^{88}$ See Jack Boulware, "S/M Dungeon Bust," Salon Magazine, 20 July 2000, available online at http://dir.salon.com/sex/world/2000/07/20/cops/index.html. The raid occurred on 8 July 2000.

${ }^{89}$ Dave Wedge, "Fetishists Defend the Pursuit of Pain," Boston Globe, 16 July 2000, 1. ${ }^{90}$ Raphael Lewis, "At Fetishists' Fair, Attleboro is a Dirty Word," Boston Globe, 30 July 2000, B2. Indeed, the Stonewall comparison was common in the media coverage, which was generally sympathetic to the fetishists. See, for example, Amy Pagnozzi, who argues that "Bondage, Discipline and Sadomasochism activists nationwide have taken up the gauntlet, perceiving that the so-called Paddleboro case may do for fetishists what the 1969 anti-police riots by transvestites and homosexuals at the Stonewall Inn in Greenwich Village did for the gay rights movement." Amy Pagnozzi, "Kinky Find A Cause In 'Paddleboro'," Hartford Courant, 9 March 2001, online at http://bdsmboard.fetishexchange.org/ubb/Forum38/HTML/000068.html. See also Michelle Chihara, "Spank You Very Much," Boston Phoenix (28 September - 5 October 2000) http://www.bostonphoenix.com/archive/features/00/09/28/s_m.html.

${ }^{91}$ See Pagnozzi, "Kinky Find A Cause In 'Paddleboro'."

${ }^{92}$ It is important to recognize, of course, that legal charges are not the only, nor even the primary, means by which erotic dissidents are socially disciplined. Carol Queen noted that even though the charges were likely to be dropped, "the damage has been done: they've been harassed, humiliated, arrested, named and pictured in the Boston Globe. This is the sort of thing that can still affect child custody and employment, freak out friends and parents, and seriously impact a person's life." Carol Queen, "So You Still Think It's a Free Country," Good Vibes Magazine, August 2000, online at http://www.goodvibes.com/cgi-bin/sgdynamo.exe?HTNAME=magazine/our_regulars/queen_on-line/200008.html.

${ }^{93}$ See, for example, Steve Hogan and Lee Hudson, Completely Queer: The Gay and Lesbian Encyclopedia (New York: Henry Holt and Company, 1998); see also Jonathan Ned Katz, Gay American History: Lesbians and Gay Men in the USA (New York: Plume, 1992). 
94 On the original reaction see Alex Kershaw, "Love Hurts," The Guardian, 23 November 1992, 6; on the reaction to the European Court's decision see Geoff Meade and Zoe Brennan, "Anger at Euro-Court 'Sex-Life Intrusion' Ruling," Press Association, 19 February 1997.

${ }^{95}$ Nick Barlay, "Real lives: Mr Blowup and Chums," The Guardian, 2 August 2000, 16. Barlay also attributes the attitude change to the case against Club Whiplash, a Putney S\&M club, whose owner was acquitted by a jury on "Disorderly House" charges based on consensual activities which took place in the club.

${ }^{96}$ After the Long Beach busts mentioned above, for example, one of the officers was asked why they didn't just make the bust during the auction "when they had determined that a probable violation had occurred"; his response is quite telling: "There were a lot of people there ... and not many police officers. Hell, we'd have had a riot. We would have been eaten alive!" "Another Slave Auction Bust," NewsWest, 1 October 1976. 